\title{
AGING OF MONETARY SAVING PROPOSITION FORMULATED FROM \\ THE FIRST-AND THE THIRD-PERSON PERSPECTIVES AS A FACTOR MODULATING THE FRAMING EFFECT
}

\author{
Oleksiy POLUNIN \\ Visiting researcher \\ at the Institute of Experimental Psychology, Slovak Academy of Sciences \\ Dúbravska cesta 9, 81364 Bratislava, Slovak Republic \\ Institute of Social and Political Psychology \\ vul. Andrievska 15, Kyiv, 04070 Ukraine \\ E-mail: polunin-alex@yandex.ru
}

\begin{abstract}
The article uncovers the role of aging of monetary saving proposition in its topical mental accounting. The monetary saving propositions were formulated from the first- and the third-person perspective to investigate whether a self-other discrepancy impacts on an aging of saving proposition. Also, the absolute and relative amount of monetary saving was varied in two stages (high vs. low), and two dates of the beginning of a sell-out were applied (past and present). The discrepancy between aging of propositions formulated from the first and the third person perspectives appears to have a different impact on the high and low relative monetary savings, which seems to be almost opposite. A high relative saving proposition ages quicker than a low relative one, but only when it is formulated from the first person perspective. When a saving proposition is formulated from a third-person perspective, aging runs quicker for low relative saving, and a high relative saving proposition seems to age slower. Correspondingly, the framing effect is modulated by two factors: 1) aging of monetary saving proposition and 2) personal perspective in formulation of saving proposition.
\end{abstract}

Key words: decision making, topical mental account, framing effect, temporal process, aging, personal perspective

\section{INTRODUCTION}

Studies on decision making have been raised to an important research field, as in modern cognitive psychology as well as in microeconomics (Kahneman, Tversky, 1979,

The publication was made possible through the support of the grant "The Limits of Scientific Explanation" from the John Templeton Foundation.
1984; Barberis et al., 2001; Frederick, Loewenstein, O’Donoghue, 2002; Fehr, Gächter, 2000). Within this field the studies on processing of temporal information in decision making show a quite impressive trend and they form a separate branch of research in decision making (Loewenstein, 1987; Prelec, 2004; Prelec, Loewenstein, 1997; Frederick, Loewenstein, O’Donoghue, 2002). These studies uncover the different aspects of influence of temporal information on decision outcome. At the same time, there is a

DOI: $10.21909 /$ sp.2013.02.630 
number of unsolved problems, considering the role of temporal processes in decision making, like modeling of discounting function under different conditions, comparison of money and time losses, difference in subjective evaluation of distant and proximal gains and so on (Frederick, Loewenstein, O'Donoghue, 2002; Read, 2001; Soman, 2001). Among other opened questions, there is also a newly proposed idea of multiplicity of temporal processes involved in topical decision making (Polunin, 2011a), one aspect of which will be studied here.

Another branch of studies aims to uncover the effects caused by the consideration of the first- and the third-person perspective on a decision outcome (Krishnamurthy, Kumar, 2002). Social transactions involve both, the ability to identify with others and the ability to distinguish ourselves from others. The first-person-perspective (1PP) can be considered as a basic constituent of a "self" which enables us to model the subjective experience and shapes our behavior. However in games, some decisions require the ability to foresee the decision of the counterpart, which can be achieved by taking the third person perspective (3PP) on the problem situation. In our earlier study (Polunin, 2010) we have shown that an aging process once applied to the subject and another time to the object of the decision (candidates for position of the president of Ukraine represented the objects) differs remarkably in velocity and consequently leads to differences in decision outcome. This finding raises the question about the role of $1 \mathrm{PP}$ and the 3PP for uncovering the time flow in topical decision making.

Introducing the idea of multitude of temporal processes influencing a decision outcome in topical mental counting, a number of temporal processes were distinguished (Polunin, 2011a). The aging of proposition is just one of them but it will be taken as the object of the study in this paper. The main question raised here is: How does the change of personal perspective influence the aging of monetary saving proposition, and consequently, how does it impact the final decision outcome? This attempt to uncover the peculiarities of the aging process for the 3PP should contribute to further specification and classification of the temporal processes relevant for topical decision making. The assumption is that the cognitive representation of time flow for the first-personperspective (1PP) differs from that of the third-person-perspective (3PP). Consequently, each of them differently impacts the aging of monetary saving proposition, which leads to different decision outcomes.

In the first step, we are going to pay attention to topical mental accounting presented from the 1PP and the 3PP in the present time mode. In addition to the analysis of positive responses to a saving proposition, we will also use the manifestation of the framing effect in order to uncover some differences between the topical mental account running for the tasks formulated from the $1 \mathrm{PP}$ and the 3PP. In the second step, the impact of proposition aging on topical mental account and the corresponding manifestation of the framing-effect will be studied.

\section{A Topical Mental Accounting Presented from the First- and the Third-person- perspective in the Present Time Mode and Manifestation of Corresponding Framing Effects}

Tversky and Kahneman (1981) have argued that all individuals develop an account- 
ing system with which to manage the sequence of financial transactions that they encounter. They proposed the experimental Jacket and Calculator problem ${ }^{1}$ to demonstrate a topical mental account. Since that time a number of studies have been done aiming to uncover different aspects of topical mental accounting and the related framing effect (Levin et al., 1998; Miller, Fagley, 1991; Kühberger, 1998). But the Jacket and Calculator problem can be formulated not only from the first-person-perspective (1PP), but also from the third-person-perspective (3PP). This variation changes the person saving money and it must modulate the run of topical account. Consequently, a variation in the manifestation of a corresponding framing effect must be expected. Thus, one of the questions to be answered is whether the mental account shows some peculiarities when a monetary saving proposition is formulated to a third person ${ }^{2}$.

${ }^{1}$ This problem involves the purchase of an expensive calculator and a cheaper jacket, as follows: Imagine that you are about to purchase a jacket for 15 USD and a calculator for 125 USD. The calculator salesman informs you that the calculator you wish to buy is on sale for 120 USD at the other branch of the store, located 20 minutes drive away. Would you make the trip to the other store? Out of a sample of 93 college students given this hypothetical choice, only $29 \%$ said they would make the trip. In a second version of the problem, the prices of jacket and calculator were changed, so that the calculator was 15 USD or 10 USD at the other branch and jacket was 125 USD in both cases. Out of 88 students presented with this version, $68 \%$ were prepared to make the trip. Thus, a 5 USD change in a high calculator price, when the jacket price was low, produced a majority "no" choice, whereas a 5 USD change in a low calculator price, when the jacked price was high, produced a majority "yes" choice. ${ }^{2}$ In this study another student will be the third person, so that the $1^{\text {st }}$ and the $3^{\text {rd }}$ person have a comparably equal monthly income.
By varying the context and experimental design it is possible to vary the manifestation of the framing effect, as shown in many studies (overviews by Kühberger, 1998; Levin et al., 1998). Also, in our previous studies (Polunin, 2009, 2011a, 2011b) we were able to reproduce the framing effect similar to the one described by Tversky and Kahneman (1981). Moreover, some variations in the manifestation of the framing effect were found depending on the activated temporal process. In the current study, the manifestation of the framing effect for propositions made in the present time mode and from the 1PP will be taken as the base-line. The impact of other experimental conditions on topical mental account will be considered in relation to this base-line.

A formulation of a monetary saving proposition from the 3PP changes the essence of a proposition in the sense that the same monetary saving is proposed not to the decision maker, but to a third person. The subject of the decision making has to foresee the decision outcome of the third person to whom the proposition is made. In order to understand the cognitive representation of a proposition made to a third person but running in the mind of the first person, our subject (the first person) will be asked to make a decision instead of the third person.

A decision making about a saving proposition formulated from the 1PP and the 3PP formally means to answer one and the same question: to act or not to act upon a saving proposition? But cognitively this question will be presented in two different ways. For the task formulated from the 1PP a subject answers the question: Is this stimulus (saving proposition) attractive enough for me? For a task formulated from the 3PP a subject has to answer a quite different question: Will 
the other subject (a student) go to another shop branch to save money? To predict a decision outcome in the last case we must consider that the general image of a university student in a developing country at the so called non-elite faculties assumes an implicit personal disposition to save money. Thus, this personal disposition will be essential for an average decision made in the name of an average student.

Moreover, research provides strong evidence of human overconfidence - overestimating the ability and accuracy of one's knowledge. People provide favorable assessments of their abilities that appear logically impossible (Alicke, 1985; Dunning et al., 1989), non-depressed students tend to have unrealistically positive perceptions of their skills. Thus, another student as a third person in the decision making task should be assessed as one who is not richer than the subject him/herself. Correspondingly, the hypothesis 1 is: a general number of positive responses given to a monetary saving proposition will be higher for tasks formulated from the third-person perspective than those from the first-person-perspective. The other student must be seen as being more ready to drive to the other store to save money than myself. Therefore, a general effect of personal perspective on a number of positive responses is to be expected.

The personal disposition of an average student (3PP), in terms of saving behavior, should erase the difference between the relative levels of monetary saving and, at the same time, make the absolute amount of saving proposition the more salient factor. On the other hand, it is well known that the relative amount of monetary saving is essential for the manifestation of the framing effect in topical mental accounting (Kühberger, 1998;
Levin et al., 1998; Moon et al., 1999). Therefore, for decisions made in the name of the third person our hypothesis 2 is: because of little importance of the relative amount of monetary saving and the dominating role of the absolute amount of saving proposition, the difference in the number of positive responses to two tasks with high and low relative savings must decline, and consequently lead to a decrease in the size of the framing effect down to its elimination.

Linguistically, the correct assignment of the $1 \mathrm{PP}$ is reflected by the use of personal pronouns ("I", "my") (Gallagher, 2000; Bermudez, 1998) and the third person perspective is reflected by the use of personal pronouns ("he/she"). Thus, we are going to manipulate a personal perspective (1PP vs. 3PP) in decision making tasks by wording the problem situation once from the 1PP and another time from the 3PP. As the general method we are using the experimental schema proposed by Tversky and Kahneman (1981) in order to demonstrate topical mental accounting in the modification proposed in our earlier publications (Polunin, 2009, 2011b).

\section{Impact of Proposition Aging on Topical Mental Account}

Aging of proposition made from the IPP. The manifestation of the framing effect has been described in numerous publications (Tversky, Kahneman, 1981; Ranyard, AbdelNabi, 1993; Kühberger, 1998; Levin et al., 1998). But these studies used tasks with propositions formulated in the present time mode. For the saving propositions beginning in the past time mode, an aging process seems to be a key factor predefining the level of its attractiveness. Previous results 
(Polunin, 2009, 2011b) have demonstrated a significant framing effect for monetary saving propositions beginning in the present time mode but an elimination of the framing effect for saving propositions beginning in the past time mode. Aging of a sell-out proposition means that there is the possibility that anything on sale few days ago may not be available now. In this sense a decision to drive to another shop to get a price reduction is kind of a risky trip. Furthermore, people know from their life experience that items with high price reduction are sold quicker than items with lower price reduction. Thus, in this study we also expect a general decline of positive responses for a saving proposition beginning in the past time mode in comparison to a similar saving proposition beginning in the present time.

On the other hand, different amounts of relative monetary saving cause a different speed of proposition aging, which predefines the manifestation of the framing effect (Polunin, 2011b). The results also show that the absolute and relative levels of monetary saving have an opposite effect on the rate of aging. A growing absolute level of monetary saving slows the aging of a proposition, which is in line with the results of other studies (Kirby, 1997; Loewenstein, 1987; Shelley, 1993). But a growing relative monetary saving increases the aging process. Similarly to our previous study (Polunin, 2011b), for the $1 \mathrm{PP}$ we also expect the following finding: attractiveness of a high relative saving proposition declines quicker than the attractiveness of a relatively low saving proposition, which, in the end, may cause the elimination of the framing effect.

On the other hand, the speed of aging must be influenced not just by a relative price reduction, but also by an absolute level of price reduction. According to Moon et al. (1999), the high absolute saving can be processed in terms of absolute value. Their results suggest that there is a threshold level above which individuals may evaluate an option in terms of absolute value of any financial gain rather than its relative, topical value. Thus the higher the absolute saving is, the more it should be valued and that should inhibit the effect of the relative size of a price reduction. In this sense, for high absolute savings the aging process must be less dependent on the relative level of saving. It might also be assumed that an increase of absolute saving proposition up to the threshold level should raise the percentage of positive responses given to both low and high relative savings, but without essentially raising the size of the framing effect (hypothesis 3). In order to examine this assumption, in contrast to our previous studies, we are going to use much higher absolute monetary savings, $40 \mathrm{UAH}$ and $60 \mathrm{UAH}^{3}$.

Aging of proposition made from the $3 P P$. Let us assume that the mental representation of a third person has its own temporal dimension, a different one from the temporal dimension of the subject's own self presentation. Consequently, the aging process should be different for the subject him/herself and for a $3^{\text {rd }}$ person. Our study (Polunin, 2010) on the role of aging in electoral decision making supports this assumption. Thus, the impact of aging on subjective evaluation of a proposed price reduction would essentially vary depending on the person-perspective given in the task formulation. Consequently, a decision assigned to the third per-

${ }^{3} \mathrm{UAH}$ or Hrivna is the national Ukrainian currency. In the previous studies were used the savings of $15 \mathrm{UAH}, 20 \mathrm{UAH}$, and $30 \mathrm{UAH}$. 
son should differ from a decision made from the 1PP.

For the 1PP, a decision situation can be reflected through the following question: Will the cheaper item (headphone) be available to buy at the other branch of the store or will they be already sold out? The answer is predefined by the gradient of subjective proposition aging. A proposition with higher relative price reduction ages quicker than a proposition with a lower one. This logic explains our finding on the speed of aging in previous studies (Polunin, 2009, 2011b). However, a positive decision for a task formulated from the 3PP can be reflected through the following question: Will another student be inclined to save a proposed amount of money? Will he/she go to the other shop to save 40 UAH despite the fact that this item went on sale 3 days ago? The change in the readiness to risk a drive to get a price reduction should be the key factor for emerging differences between the decision-outcomes for the 1PP- and the 3PP-task. Consumers are more satisfied in environments that are characterized by low levels of uncertainty regarding the gain in form of price reduction. However, while consumers themselves may be risk-averse in gaining a price reduction proposed few days ago, do they predict others to be similarly risk-averse? Or will others be seen as more risk-seeking than the self? The risk-as-feelings thesis proposed by Hsee and Weber (1997) suggest that when faced with options that vary in the level of riskiness in the outcome, in our case gaining a price reduction, people base their choices on their feelings toward the risk. They believe that decision makers are only partially able to use feelings as a factor when estimating the risk preferences of others, especially abstract others, because of the inherent dif- ficulty in empathizing with the feelings of others. Given that people are themselves largely risk-averse in their gaining decisions (Kahneman, Tversky, 1979) and only partly able to empathize with the risk feeling of others we could assume (hypothesis 4) that people would be less risk-seeking when the decision context is self-focused than when it is other-focused. According to this assumption we could expect: 1) for the tasks formulated from the 1PP, a usual high aging of propositions with high relative price reduction and a low aging for propositions with low relative saving; 2) for the tasks formulated from the 3PP, a speed of aging of high and low relative savings can be the same or even become inverse, so that a proposition with high relative price reduction ages slower than a proposition with a low relative saving.

In order to examine the list of assumptions, we first have to reproduce a classical framing effect similar to the one described by Tversky and Kahneman (1981). Thereafter the contribution of an aging process and its variations depending on the $1 \mathrm{PP}$ and the $3 \mathrm{PP}$ and the absolute and relative levels of monetary saving will be studied.

\section{METHOD}

\section{Design}

The study was carried out at the Technical University of Kyiv, Ukraine. Subjects were randomly assigned to the each version of the task. Each subject solved only one decision problem. As well as their choices people were asked to indicate their age and sex. The experimental task was adapted from the "Jacket and Calculator" problem (Tversky, Kahneman, 1981) and was similar to the tasks 
Table 1. Experimental conditions. The original prices were $1190 \mathrm{UAH}$ and $180 \mathrm{UAH}$ for the price reduction of $60 \mathrm{UAH}$, and $790 \mathrm{UAH}$ and $120 \mathrm{UAH}$ for the price reduction of 40 UAH

\begin{tabular}{|c|c|c|c|c|}
\hline \multirow{2}{*}{$\begin{array}{l}\text { Time mode and } \\
\text { absolute saving }\end{array}$} & \multicolumn{2}{|c|}{$1^{\text {st }}$ person perspective, relative saving } & \multicolumn{2}{|c|}{$3^{\text {rd }}$ person perspective, relative saving } \\
\hline & saving 5\% & saving $33.3 \%$ & saving $5 \%$ & saving $33.3 \%$ \\
\hline $\begin{array}{l}\text { Present, } 0 \text { days, } \\
60 U A H\end{array}$ & $\begin{array}{c}1190-60=1150 \\
\text { UAH }\end{array}$ & $\begin{array}{c}180-60=120 \\
\text { UAH }\end{array}$ & $\begin{array}{c}1190-60=1150 \\
\text { UAH }\end{array}$ & $\begin{array}{c}180-60=120 \\
\text { UAH }\end{array}$ \\
\hline $\begin{array}{l}\text { Past, } 3 \text { days, } \\
60 \text { UAH }\end{array}$ & $\begin{array}{c}1190-60=1150 \\
\text { UAH }\end{array}$ & $\begin{array}{c}180-60=120 \\
\text { UAH }\end{array}$ & $\begin{array}{c}1190-60=1150 \\
\text { UAH }\end{array}$ & $\begin{array}{c}180-60=120 \\
\text { UAH }\end{array}$ \\
\hline $\begin{array}{l}\text { Present, } 0 \text { days, } \\
40 U A H\end{array}$ & $\begin{array}{c}790-40=750 \\
\text { UAH }\end{array}$ & $\begin{array}{c}120-40=80 \\
\text { UAH }\end{array}$ & $\begin{array}{c}790-40=750 \\
\text { UAH }\end{array}$ & $\begin{array}{c}120-40=80 \\
\text { UAH }\end{array}$ \\
\hline $\begin{array}{l}\text { Past, } 3 \text { days, } \\
40 U A H\end{array}$ & $\begin{array}{c}790-40=750 \\
\text { UAH }\end{array}$ & $\begin{array}{c}120-40=80 \\
\text { UAH }\end{array}$ & $\begin{array}{c}790-40=750 \\
\text { UAH }\end{array}$ & $\begin{array}{c}120-40=80 \\
\text { UAH }\end{array}$ \\
\hline
\end{tabular}

used in our previous studies (Polunin, 2009, 2011). According to the raised assumptions, the absolute and the relative amount of monetary savings were taken as the independent variable. Each of them varied in two stages, the high and the low one. The amount of money to be saved was $60 \mathrm{UAH}$ and $40 \mathrm{UAH}^{4}$. The relative amount of monetary saving varied between $33.3 \%$ and $5 \%$. The time mode for the beginning of a sell-out varied in two stages: past, and present. The temporal distance varied between 0 and 3 days. The temporal distance with zero days represents the present time mode. The 3 days temporal distance was used for the past time mode. Additionally, there were task wordings given from the first- and the third-person perspective. All together there were sixteen versions of the same basic scenario: time mode (past, now) $\mathrm{x}$ two versions of task wording $(33.3 \%$ and $5 \%$ of relative price reduction) $\mathrm{x}$ two levels of absolute price reduction (60 UAH and $40 \mathrm{UAH}) \mathrm{x}$ two versions of person-perspec-

${ }^{4} \mathrm{At}$ the time of data collection the exchange rate in Kyiv was about 8.03-8.06 UAH for 1 USD, and about 10.56-10.70 UAH for 1 EUR. tive (1PP vs. 3PP), see Table 1. A subject's decision outcome was taken as the dependent variable showing his/her readiness to accept a saving proposition. We used a between subjects design typical for this kind of studies (Tversky, Kahneman 1981; Kühberger, 1998; Levin et al., 1998).

\section{Materials}

Written versions of the problem were prepared in Ukrainian. A similar wording was used in each case and only the amount of money to be saved and the temporal parameters of the situation were changed. The tasks for the 1PP were similarly formulated as in our previous studies (Polunin, 2009, 2011). The tasks for the 3PP were given as illustrated below. The participants were asked to predict what the other student would decide.

The third-person perspective in the present time mode condition.

Task 1

Please, imagine the following situation, and make a decision about it. 
Imagine that a student from the same class year comes to an electronics store and is about to purchase:

headphones for $790 \mathrm{UAH}$

and a microphone for $120 \mathrm{UAH}$.

The student chooses the headphones, but a shop assistant informs him/her that the same headphones are on sale for $750 \mathrm{UAH}$ at the other branch of the store, located 20 minutes drive away.

Would the student make the trip to the other store? (mark one box)

YES

NO

\section{Task 1}

Please, imagine the following situation, and make a decision about it.

Imagine that a student from the same class year comes to an electronics store and is about to purchase:

headphones for $790 \mathrm{UAH}$

and a microphone for $120 \mathrm{UAH}$.

The student chooses the headphones, but a shop assistant informs him/her that the same headphones went on sale 3 days ago for $750 \mathrm{UAH}$ at the other branch of the store, located 20 minutes drive away.

Would a student make the trip to the other store? (mark one box)

$$
\text { YES } \square
$$

Task 2 for the past and present time conditions was similarly formulated but for $33.3 \%$ of price reduction. For the past time mode condition the following formulation of decision situation from the 3PP was used.

\section{Subjects}

1152 students ( 72 subjects for each of the 16 experimentalconditions) between the ages of 17 and 26 (mean age 19.75 years; $76 \%$ males and $24 \%$ females) participated in the experiment. The participation was voluntary and unpaid. Each subject solved onlyone decision problem and none of the subjects participated in the experiment repeatedly. Thenumber per session ranged from 9 to 32 subjects.

\section{RESULTS}

The percentage of positive responses to a saving proposition within each experimental condition is presented in Table 2. But before examining our hypotheses concerning the framing effect, the main effects of certain single factors were checked in order to demonstrate the general tendencies in decision making under given experimental conditions. A main effect of time mode was found (past vs. present), Pearson $\chi^{2}=57.4, \mathrm{df}=1, \mathrm{p}<$ .001 . Thus, we can speak about a general decline of positive responses in the tasks with sell-out beginning in the past. The number of positive responses for a saving proposition in the present time mode, the overall condition was $65.97 \%$, but for wording of a sell-out in the past time mode it reaches only $43.75 \%$. Obviously, such loss of saving proposition attractiveness is caused by the aging as a temporal process. Based also on our previous studies (Polunin, 2009, 2011b), we may affirm that the farther in the past a saving proposition is made, the riskier it is to act upon this proposition now.

According to our assumption we have found the main effect of the personal perspective. A general number of positive responses given to a monetary saving proposition is higher for a task formulated from the 3PP $(59.9 \%)$ than for the one from the 1PP $(49.8 \%), \chi^{2}=11.8, \mathrm{df}=1, \mathrm{p}=.001$. Therefore, for over all conditions, hypothesis 1 is true. 
We also analyzed the impact of the amount of monetary saving on decision outcome. The main effect of absolute level of monetary saving, (60 UAH vs. $40 \mathrm{UAH}$ ) for over all conditions did not reach the level of significance $\left(\chi^{2}=1.4, \mathrm{df}=1, \mathrm{p}=.23\right)$. Thus, an increase of absolute saving proposition from 40 UAH to 60 UAH did not lead to a significant rise of the percentage of positive responses. Obviously, both $40 \mathrm{UAH}$ and 60 UAH savings are quite high for our subjects and therefore they cannot have a differential impact on the decisions made. But the relative level of monetary saving (5\% vs. $33.3 \%$ saving) shows a significant impact $\left(\chi^{2}=22.4\right.$, $\mathrm{df}=1, \mathrm{p}<.001)$. Over all the data, $61.8 \%$ of "yes" responses were given to $33.3 \%$ saving, while just $47.92 \%$ of "yes" responses were given to the $5 \%$ saving.

The analysis of a gender effect under particular experimental conditions has shown the following results: no significant effect for the 1PP-condition in the present time mode $\left(\chi^{2}<1, \mathrm{df}=1, \mathrm{p}=.46\right)$, and past time mode $\left(\chi^{2}<1, \mathrm{df}=1, \mathrm{p}=.46\right)$ and for the $3 \mathrm{PP}$, in the past time mode $\left(\chi^{2}<1, \mathrm{df}=1, \mathrm{p}=.87\right)$. But for the 3PP-wording in the present time mode a gender effect was marginally significant $\left(\chi^{2}=1.9, \mathrm{df}=1, \mathrm{p}=.058\right)$. Such finding goes well along with our earlier results.

People are found to believe that others process time flow quite similarly to their own. A three days aging of a proposition caused almost in all cases, in the 1PP as well as the 3PP, a significant loss of saving proposition attractiveness. Only the aging of $40 \mathrm{UAH}$ given as $33.3 \%$ of relative saving for the $3 \mathrm{PP}$ did not reach the level of significance (Table 2 ). On the other hand, an impact of aging on a run of topical mental account must be seen not through a direct comparison of decision outcomes but through change of positive responses caused by aging. This change can be described as the difference in the number of positive responses between the corresponding past and present time wordings (Table 2). Also, the difference in the manifestation of the framing effect for the tasks presented from the 1PP and 3PP serves as a fine measure for an impact of aging on the run of a topical mental account.

First Person Perspective. Comparing two versions of proposition wording (33.3\% and $5 \%$ ) in the present time mode, a significant framing effect was found for the problems formulated from the 1PP (for $60 \mathrm{UAH} \chi^{2}=6.8$, $\mathrm{df}=1, \mathrm{p}=.009$ and for $40 \mathrm{UAH} \chi^{2}=5.6, \mathrm{df}=$ $1, \mathrm{p}=.018$ ), which is the classical framing effect described in previous studies (Tversky, Kahneman, 1981; Polunin, 2009). However, for the present time mode no significant framing effect was found under the 3PP-condition. In both cases, for 60UAH and 40UAH savings, we found no significant difference between the responses given to $5 \%$ and $33.3 \%$ of relative savings, $\chi^{2}<1$, see Table 2 . This finding is in line with the assumption made in hypothesis 2. A subject making a decision in the name of the third person considers rather the absolute saving as the main factor for acting upon a personal disposition to save. Consequently it leads to the elimination of the framing effect.

A decrease of the framing effect for the 1PP tasks under the past time condition was assumed down to its full elimination. The results show that attractiveness of a high relative saving proposition (33.3\%) declines quicker than attractiveness of relatively low saving proposition (5\%), which finally causes a descending framing effect for 60 UAH saving (from $20.8 \%$ down to $16.7 \%$ ) and the elimination of the framing effect for $40 \mathrm{UAH}$ saving (from $19.5 \%$ down to $8.4 \%$ ). This finding 
Table 2. The percentage of positive responses for each experimental condition*

\begin{tabular}{|c|c|c|c|c|c|c|}
\hline \multirow{2}{*}{$\begin{array}{l}\text { Time mode } \\
\text { and absolute } \\
\text { saving }\end{array}$} & \multicolumn{3}{|c|}{$1^{\text {st }}$ person perspective } & \multicolumn{3}{|c|}{$3^{\text {rd }}$ person perspective } \\
\hline & $\begin{array}{c}\text { saving } \\
5 \%\end{array}$ & $\begin{array}{l}\text { saving } \\
33.3 \%\end{array}$ & $\begin{array}{l}\text { size of } \\
\text { framing } \\
\text { effect, \%, } \\
\text { signif. }\end{array}$ & $\begin{array}{c}\text { saving } \\
5 \%\end{array}$ & $\begin{array}{l}\text { saving } \\
33.3 \%\end{array}$ & $\begin{array}{l}\text { size of } \\
\text { framing } \\
\text { effect, \%, } \\
\text { signif. }\end{array}$ \\
\hline $\begin{array}{l}\text { Present, } \\
0 \text { days, } \\
60 \text { UAH }\end{array}$ & $54.2 \%$ & $75 \%$ & $\begin{array}{l}20.8 \% \\
\chi^{2}=6.8 \\
\mathrm{df}=1 \\
p=.009\end{array}$ & $69.4 \%$ & $76.4 \%$ & $\begin{array}{l}7 \% \\
\chi^{2}<1 \\
\text { non sign. }\end{array}$ \\
\hline $\begin{array}{l}\text { Difference in } \\
\% \text { of "yes" } \\
\text { between } \\
\text { Present and } \\
\text { Past } \\
\text { conditions }\end{array}$ & $\begin{array}{l}\Delta=20.9 \% \\
\chi^{2}=6.35 \\
\mathrm{df}=1 \\
\mathrm{p}=.018\end{array}$ & $\begin{array}{l}\Delta=25 \% \\
\chi^{2}=9.6 \\
\mathrm{df}=1 \\
\mathrm{p}=.003\end{array}$ & 1 & $\begin{array}{l}\Delta=30.5 \% \\
\chi^{2}=13.5 \\
\mathrm{df}=1 \\
\mathrm{p}<.001\end{array}$ & $\begin{array}{l}\Delta=20.8 \% \\
\chi^{2}=6.96 \\
\mathrm{df}=1 \\
\mathrm{p}=.013\end{array}$ & - \\
\hline $\begin{array}{l}\text { Past, } \\
3 \text { days, } \\
60 U A H\end{array}$ & $33.3 \%$ & $50 \%$ & $\begin{array}{l}16.7 \% \\
\chi^{2}=4.1 \\
\mathrm{df}=1 \\
p=.04\end{array}$ & $38.9 \%$ & $55.6 \%$ & $\begin{array}{l}16.7 \% \\
\chi^{2}=4, \mathrm{df}=1 \\
p=.04\end{array}$ \\
\hline $\begin{array}{l}\text { Present, } \\
0 \text { days, } \\
40 \text { UAH }\end{array}$ & $47.2 \%$ & $66.7 \%$ & $\begin{array}{l}19.5 \% \\
\chi^{2}=5.6 \\
p=.018\end{array}$ & $68.1 \%$ & $70.8 \%$ & $\begin{array}{l}2.7 \% \\
\chi^{2}<1 \\
\text { non sign. }\end{array}$ \\
\hline $\begin{array}{l}\text { Difference in } \\
\% \text { of "yes" } \\
\text { between } \\
\text { Present and } \\
\text { Past } \\
\text { conditions }\end{array}$ & $\begin{array}{l}\Delta=15.3 \% \\
\chi^{2}=3.5 \\
\mathrm{df}=1 \\
\mathrm{p}=.08\end{array}$ & $\begin{array}{l}\Delta=26.4 \% \\
\chi^{2}=10 \\
\mathrm{df}=1 \\
\mathrm{p}=.003\end{array}$ & - & $\begin{array}{l}\Delta=27.8 \% \\
\chi^{2}=11.1 \\
\mathrm{df}=1 \\
\mathrm{p}=.001\end{array}$ & $\begin{array}{l}\Delta=11.7 \% \\
\chi^{2}=1.96, \\
\mathrm{df}=1 \\
\mathrm{p}=.22, \\
\text { non sign. }\end{array}$ & - \\
\hline $\begin{array}{l}\text { Past, } \\
3 \text { days, } \\
40 U A H\end{array}$ & $31.9 \%$ & $40.3 \%$ & \begin{tabular}{|l|}
$8.4 \%$ \\
$\chi^{2}=1.08$, \\
$\mathrm{df}=1$ \\
$\mathrm{p}=.3$ \\
non sign. \\
\end{tabular} & $40.3 \%$ & $59.7 \%$ & $\begin{array}{l}19.4 \% \\
\chi^{2}=5.4 \\
\mathrm{df}=1 \\
p=.02\end{array}$ \\
\hline
\end{tabular}

* Size of framing effect was calculated as the difference between the corresponding conditions with $33.3 \%$ and $5 \%$ savings. Aging of proposition is presented by the difference in $\%$ of "yes" between Present and Past conditions

is in agreement with our previous studies (Polunin, 2009, 2011b). A descent of framing effect can be explained in this case through a quicker aging of a higher relative saving proposition. It is possible that the rather high price reduction of $60 \mathrm{UAH}$ reached the upper threshold level, when the absolute level of price reduction matters more than the rela- 
tive one. Thus, only a decrease but not the full elimination of the framing effect was observed. A difference in the aging rate of two absolutely equal but relatively different saving propositions, as shown in this study as well, seems to be sufficient for an essential weakening of the framing effect up to its entire elimination.

Hypothesis 3 assumed that the higher the absolute saving is, the more it should be valued and thus it should inhibit the effect of relative price cut. As we can see from Table 2 , for the $60 \mathrm{UAH}$ saving, the 1PP, and the present time condition the number of "yes" for both $5 \%$ and $33.3 \%$ saving is higher than for the corresponding $40 \mathrm{UAH}$ price cut. At the same time, the size of the framing effect is almost equal $-20.8 \%$ for 60 UAH and $19.5 \%$ for $40 \mathrm{UAH}$. An increase of absolute saving proposition up to the high level raises the percentage of positive responses given to both low and high relative savings, but without the essential rise of the framing effect. In contrast, for the 3PP in the present time condition the number of "yes" responses is almost equal for low and high relative and absolute price reduction, having as a consequence the elimination of the framing effect.

The aging process for $60 \mathrm{UAH}$ absolute savings proposed to the first person seems to be less dependent on the relative level of the saving. The loss of proposition attractiveness for $5 \%$ and $33.3 \%$ of the price cut correspondingly equals $20.5 \%$ and $25 \%$, whereas for $40 \mathrm{UAH}$ of absolute saving the corresponding differences between the present and past time conditions equals $15.3 \%$ and $26.4 \%$.

For the Third-Person Perspective, the impact of aging on the manifestation of the framing effect seems to show an opposite pattern (Table 2). The attractiveness of high rela- tive saving proposition (33.3\%) declines slower than the attractiveness of relatively low saving proposition (5\%). Finally resulting in a pronounced framing effect under the past time condition. This pattern holds for both $40 \mathrm{UAH}$ and $60 \mathrm{UAH}$ savings. In other words, the propositions made from the 1PP and 3PP demonstrate an essential discrepancy in the aging rate depending on the relative level of monetary saving. Aging of proposition formulated from the 1PP leads to a rather converging trend of positive responses and consequently to the elimination of the framing effect, whereas the tasks formulated from the 3PP show an divergent tendency in the number of "yes" responses given to high and low level relative savings and finally to a rise in the framing effect (Figure $1 \mathrm{a}, \mathrm{b}, \mathrm{c}, \mathrm{d}$ ).

When subjects are faced with options that vary in the level of riskiness of the outcome, in our case getting a price reduction proposed in the past, they base their choices on their feelings toward the risk. Furthermore, let as agree that an old price cut by $5 \%$ is a less risky proposition than an equally old $33.3 \%$ price cut. Considering the difference in aging between the $5 \%$ and $33.3 \%$ saving propositions, it might be concluded that people seem to be less risk-seeking when the decision context is 1PP-focused than when it is 3PP-focused. According to our assumption, for the tasks formulated from the 1PP we found the usual high aging of propositions with high relative price reduction and a low aging for propositions with low relative saving. But for the tasks formulated from the 3PP, the speed of aging of relatively high and low of propositions got inversed, so that a proposition with high relative price reduction aged slower than a proposition with a low relative saving. The clear framing effect 


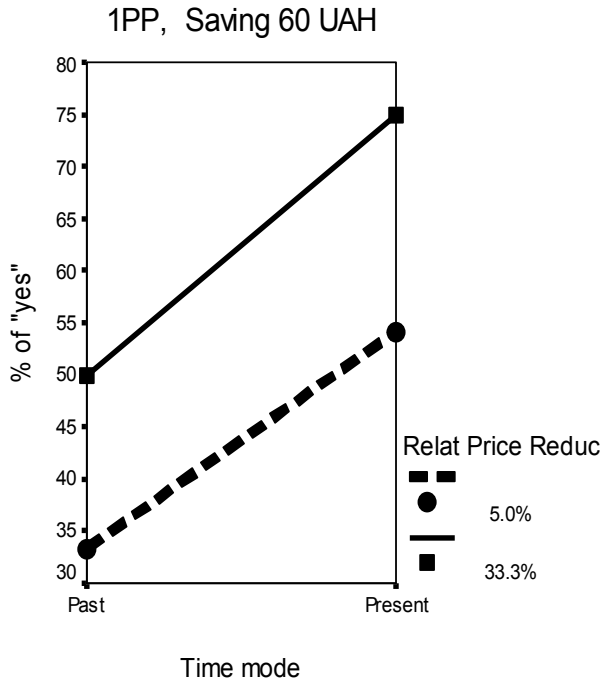

Figure 1a

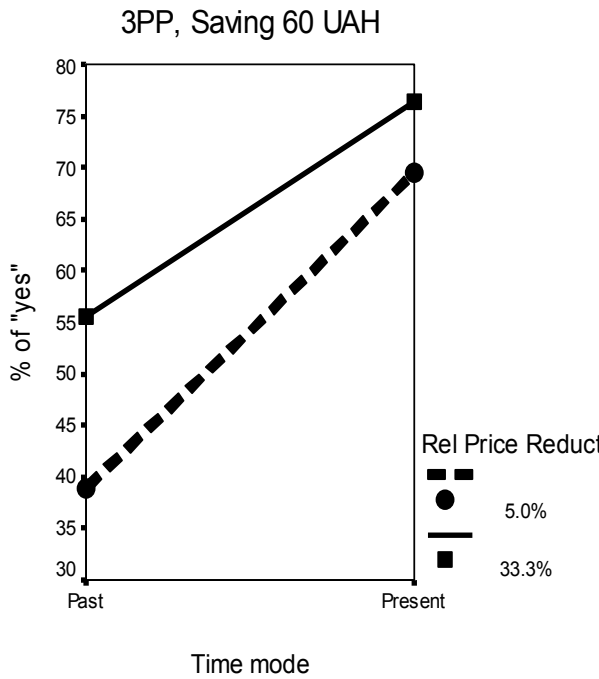

Figure 1c

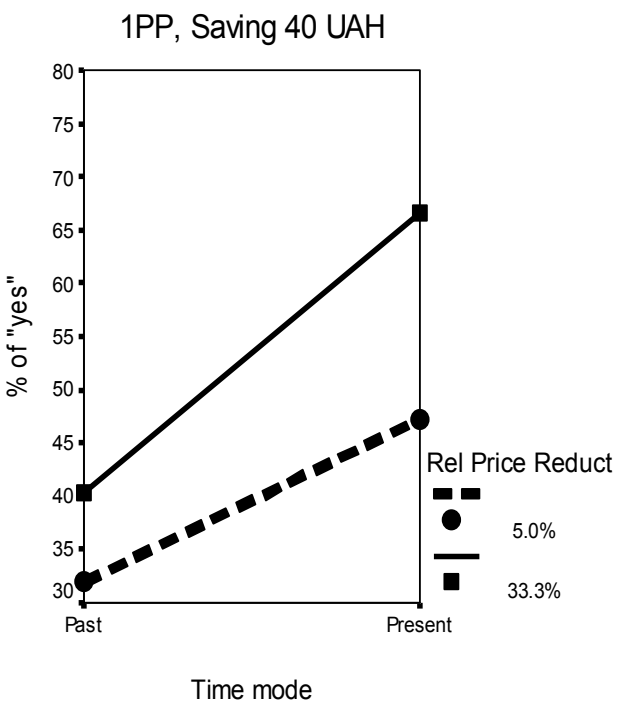

Figure 1b

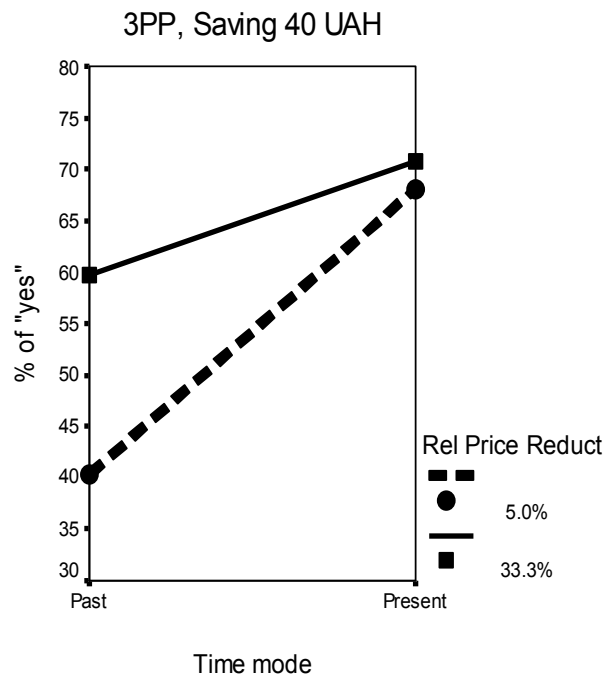

Figure 1d

Figure 1a, b, c, d. The changes in the number of "yes" responses by transition from the present to past time condition. Figures $1 \mathrm{a}$ and $1 \mathrm{~b}$ present the results for 1PP-tasks, whereas Figures $1 \mathrm{c}$ and $1 \mathrm{~d}$ present the $3 \mathrm{PP}$-tasks. Aging of saving proposition is presented by the difference between the present and past conditions. An angle between each line and horizon reflects a corresponding speed of proposition aging 
for the 3PP tasks under the past time condition helps to demonstrate this property of aging. It also speaks for the truth of hypothesis 4. Thus, in accordance with the risk-asfeeling thesis (Hsee, Weber, 1997), we observed greater aging of higher relative price reduction for task wordings from the $1 \mathrm{PP}$, as opposed to the 3PP task wordings, where lower relative savings showed greater aging. People seem to be less risk-seeking when they make their own decisions than when they predict the decisions of others in similar environments.

Analyzing the differences for the 1PP and 3PP conditions for each level of relative saving, we can speak about a discrepancy between the aging of 1PP and 3PP monetary saving propositions (Table 2). But such comparison does not give the exact picture of the aging process for each one unit of money (1 UAH) for its each day of being in a saving proposition. Thus, the influence of absolute and relative price reduction on the aging rate was recalculated for each 1 UAH proposed to be saved, similarly to what was done in our previous study (Polunin, 2011b). This recalculation corresponds to the approach in the calculation of discounting rate used in the discounting utility theory (Frederick, Loewenstein, O'Donoghue, 2002; Prelec, Loewenstein, 1997). Calculating the speed of proposition aging for each past day and for each $1 \mathrm{UAH}$ of price reduction we get the following results (Table 3). Calculation was done using the formula: (difference in $\%$ of "yes" between the present and the past time) : 3 days of waiting : absolute amount to save $=[\% /(U A H /$ day $)]$.

The results for the 1PP seem to go along with our previous study (Polunin, 2011b). If the percentage of "yes" responses is considered as the level of attractiveness of the sell-out proposition, then each 1 UAH losses the attractiveness quicker for $40 \mathrm{UAH}$ than for $60 \mathrm{UAH}$ price reduction, given that both of them belong to the same level of relative price reduction. The higher the absolute saving, the higher its value and smaller its rate of aging. This result is in agreement with the findings of Kirby (1997), Loewenstein (1987), and Shelley (1993) who have shown that large outcomes are discounted at a lower rate

Table 3. The rate of aging of 1 UAH proposed for the saving depending on the absolute and relative price reduction. Upper part of the table presents the results for the 1PP and the lower part presents the results for the $3 \mathrm{PP}$

\begin{tabular}{|c|c|c|c|}
\hline \multirow{2}{*}{$1 P P$} & & \multicolumn{2}{|c|}{ Relative price reduction } \\
\hline & & $5 \%$ & $33.3 \%$ \\
\hline \multirow{2}{*}{$\begin{array}{l}\text { Absolute price } \\
\text { reduction }\end{array}$} & $40 \mathrm{UAH}$ & $\begin{array}{l}15.3 \%: 3 \text { days }: 40 \mathrm{UAH}= \\
0.127 \% \text { for each } 1 \mathrm{UAH} / \text { day }\end{array}$ & $\begin{array}{l}26.4 \%: 3 \text { days }: 40 \mathrm{UAH}= \\
0.22 \% \text { for each } 1 \mathrm{UAH} / \text { day }\end{array}$ \\
\hline & $60 \mathrm{UAH}$ & $\begin{array}{l}20.9 \%: 3 \text { days }: 60 \mathrm{UAH}= \\
0.116 \% \text { for each } 1 \mathrm{UAH} / \text { day }\end{array}$ & $\begin{array}{c}25 \%: 3 \text { days }: 60 \mathrm{UAH}= \\
0.139 \% \text { for each } 1 \mathrm{UAH} / \text { day }\end{array}$ \\
\hline $3 P P$ & & $5 \%$ & $33.3 \%$ \\
\hline \multirow{2}{*}{$\begin{array}{l}\text { Absolute price } \\
\text { reduction }\end{array}$} & $40 \mathrm{UAH}$ & $\begin{array}{l}27.8 \%: 3 \text { days }: 40 \mathrm{UAH}= \\
0.232 \% \text { for each } 1 \mathrm{UAH} / \text { day }\end{array}$ & $\begin{array}{c}11.7 \% \text { 3days : } 40 \mathrm{UAH}= \\
0.097 \% \text { for each } 1 \mathrm{UAH} / \text { day }\end{array}$ \\
\hline & $60 \mathrm{UAH}$ & $\begin{array}{l}30.5 \%: 3 \text { days }: 60 \mathrm{UAH}= \\
0.169 \% \text { for each } 1 \mathrm{UAH} / \text { day }\end{array}$ & $\begin{array}{c}20.8 \%: 3 \text { days }: 60 \mathrm{UAH}= \\
0.116 \% \text { for each } 1 \mathrm{UAH} / \text { day }\end{array}$ \\
\hline
\end{tabular}


than small ones. At the same time, our previous (Polunin, 2011b) and current results show that a smaller relative price reduction ages slower than a higher relative price reduction, provided that both belong to the same level of absolute price reduction. However, this is not the case for the 3PP.

For the saving propositions formulated from the 3PP (Table 3), each 1 UAH losses its attractiveness more when it is proposed for saving in the condition with low relative price reduction than when it is proposed for saving under high level of relative price reduction. The latter fact could explain the appearance of the framing effect under the past time condition (see Figures 1c and 1d). Generally for 3PP, we can conclude that the higher the difference in the rate of aging of two propositions, the quicker the framing effect for tasks with sell-out beginning in the past time mode. The asymmetry in aging between the $1 \mathrm{PP}$ and the $3 \mathrm{PP}$ in relation to the propositions with $5 \%$ and $33.3 \%$ relative price reduction can also be interpreted as an argument for hypothesis 4 .

\section{DISCUSSION}

The temporal processes involved in the development of a cognitive representation of a monetary saving proposition shape its mental "life history" and a correspondingly its subjective evaluation. For the saving propositions beginning in the past, an ageing process seems to be a key temporal process influencing subjective attractiveness of the proposition, predefining a decision outcome and the manifestation of the framing effect. We examined how decision behavior in getting a price reduction varies depending on whether the choices are self-focused or other-focused. Our ability to represent our own and another's thoughts concerning time may be intimately tied together, but under certain conditions this ability results in quite different decision outcomes. The difference in the manifestation of the framing effect for sell-outs beginning in the past points to a self-other discrepancy, in that people report lower risk readiness themselves than they think the others would. This finding is in agreement with a study by Krishnamurthy and Kumar (2002), who have shown similar self-other discrepancies but in waiting time decisions.

Based on the available results, the previously introduced idea of multiplicity of temporal processes and the proposed classification of temporal processes (Polunin, 2011a) become part of a further development. This experiment is the first step in distinguishing between the temporal processes represented from the first- and the third-person perspectives. The discrepancy between aging for the first- and the third-person perspectives appears in their different impact on the high and low relative monetary savings, which seems to be almost opposite. A high relative saving proposition ages quicker than a low one, but only in the case when it is formulated from the first person perspective. For a proposition formulated from a third person perspective, aging runs quicker for a low relative saving, and a high relative saving proposition seems to age slower. These different properties of a proposition aging given from the first- and the third-person-perspectives provide the ground for labeling them as two different processes. The described differences between the first- and the third-person perspectives on the representation of aged proposition could be of interest for development of financial products as well as for advertising of sell-outs. Briefly, the dis- 
tinguished temporal processes mean that a subjective value of unit of money (1 UAH) proposed for saving varies differently at the very same time distance, depending on the activated temporal processes.

The described differences in the manifestation of the framing effect could be of interest for modeling of behavior in games and other human interactions. This and previous studies show that the framing effect for the first-person perspective declines in the past time mode up to its total elimination. But opposite from the third-person perspective, the framing effect begins to grow in the past time mode and is eliminated in the present time mode. Knowledge about such discrepancy could be useful in the prevention of mistaken forecast of individual behavior.

Finally, there is a limitation to our study that should be addressed in future work. Aging as a temporal process was connected to a risk-feeling, but the design of our study did not allow explicitly to measure the level of risk-feelings. We just assumed that risk, not to get a wanted item at the reduced price, rises with growing time distance between the present time moment and the beginning of a sell-out. Future work in this area should examine, in a more direct way, this interconnection between a subjective perception of risk "not to get an item" and time distance.

Received November 28, 2012

\section{REFERENCES}

ALICKE, M.D., 1985, Global self-evaluation as determined by the desirability and controllability of trait adjectives. Journal of Personality and Social Psychology, 49, 1621-1630.

BARBERIS, N., HUANG, M., SANTOS, T., 2001, Prospect theory and asset prices, Quarterly Journal of Economics, 116, 1-53.
BERMUDEZ, J.L., 1998, The paradox of selfconsciousness, Cambridge MA: MIT Press.

DUNNING, D., MEYEROWITZ, J.A., HOLZBERG, A., 1989, Ambiguity and self-evaluation: The role of idiosyncratic trait definitions in self-serving assessments of ability. Journal of Personality and Social Psychology, 57, 1082-1090.

FEHR, E., GÄCHTER, S., 2000, Cooperation and punishment in public goods experiments. American Economic Review, 90, 4, 980-994.

FREDERICK, S., LOEWENSTEIN, G., O'DONGHUE, T., 2002, Time discounting and time preference: A critical Review. Journal of Economic Literature, XL, 351-401.

GALLAGHER, S., 2000, Philosophical conceptions of the self: Implications for cognitive science. Trends in Cognitive Sciences, 4, 14-21.

HSEE, C.K., WEBER, E.U., 1997, A fundamental prediction error: Self-other discrepancies in risk preference. Journal of Experimental Psychology: General, 126, 1, 45-53.

KAHNEMAN, D., TVERSKY, A., 1979, Prospect theory: An analysis of decision under risk. Econometrica, 47, 263-291.

KAHNEMAN, D., TVERSKY, A., 1984, Choices, values and frames. American Psychologist, 39, 341350 .

KIRBY, K.N., 1997, Bidding on the future: Evidence against normative discounting of delayed rewards. Journal of Experimental Psychology: General, 126, 54-70.

KRISHNAMURTHY, P., KUMAR, P., 2002, Selfother discrepancies in waiting time decisions. Organizational Behaviour and Human Decision Processes, 87, 2, 207-226.

KÜHBERGER, A., 1998, The influence of framing on risky decisions: A meta-analysis. Organizational Behaviour and Human Decision Processes, $75,1,23-55$

LEVIN, I.P., SCHNEIDER, S.L., GAETH, G.J., 1998, All frames are not created equal: A topology and critical analysis of framing effects. Organizational Behaviour and Human Decision Processes, 76, 2, 149-188.

LOEWENSTEIN, G., 1987, Anticipation and the valuation of delayed consumption. Economic Journal, 97, 387, 666-684.

MILLER, P.M., FAGLEY, N.S., 1991, The effect of framing, problem variations, and providing rationale on choice. Personality and Social Psychology Bulletin, 17, 517-522.

MOON, P., KEASEY, K., DUXBURY, D., 1999, Mental accounting and decision making: The rela- 
tionship between relative and absolute savings. Journal of Economic Behavior \& Organization, 38, 145-153.

POLUNIN, O., 2009, Temporal dimension of the framing effect in topical mental accounting. Studia Psychologica, 51, 4, 434-355.

POLUNIN, O., 2010, Chasovy freyming rishennya vyborzya: Starinnya subjekta i starinnya proposizii. Naukovi Studii iz Sozialnoi ta Politichnoi Psikhologii: Zb. st. / NAPN Ukrainy, Ins-t soz. ta polit. psihologii. - K.: Milenium - 28, 31, 297 311. [Temporal framing of electoral decision: An aging of subject and an aging of proposition. Scientific Studies on Social and Political Psychology / National Academy of Pedagogical Sciences of Ukraine, Kyiv: Melenium, 28, 31, 297-311] (In Ukrainian)

POLUNIN, O., $2011 \mathrm{a}$, Temporal processes in the topical mental accounting. Studia Psychologica, 53, 3, 275-291

POLUNIN, O., 2011b, Relative amount of monetary saving as a factor of proposition aging and elimination of the framing effect. Studia Psychologica, 53, 4, 327-338.
PRELEC, D., 2004, Decreasing impatience: A criterion for non-stationary time preference and hyperbolic discounting. Scandinavian Journal of Economics, 106, 3, 511-532.

PRELEC, D., LOEWESTEIN, G., 1997, Beyond time discounting. Marketing Letters, 8, 1, 97-108.

READ, D., 2001, Is time-discounting hyperbolic or subadditive? Journal of Risks and Uncertainty, 23, 1, 5-32.

RANYARD, R., ABDEL-NABI, D., 1993, Mental accounting and the process of multiattributive choice. Acta Psychologica, 84, 161-177.

SHELLEY, M.K., 1993, Outcome signs, question frames, and discount rates. Management Science, 39, 7, 806-815.

SOMAN, D., 2001, The mental accounting of sunk time costs: Why time is not like money. Journal of Behavioral Decision Making, 14, 3, 169185.

TVERSKY, D., KAHNEMAN, A., 1981, The framing of decisions and the psychology of choice. Science, 211, 453-458.

\title{
STARNUTIE NÁVRHU PEŇAŽNEJ ÚSPORY Z POHL'ADU PRVEJ A TRETEJ OSOBY AKO FAKTOR REGULUJÚCI EFEKT RÁMCOVANIA
}

\author{
O. Polu n in
}

Súhrn: Článok odhal’uje úlohu návrhu peňažnej úspory v aktuálnom mentálnom účtovaní. Návrhy peňažnej úspory boli formulované z pohl'adu prvej a tretej osoby tak, aby skúmali či, má rozdiel self-other dopad na starnutie návrhu úspory. Menila sa tiež absolútna a relatívna výška peňažnej úspory na dvoch úrovniach (vysoká vs. nízka), a použili sa aj dva dátumy začiatku výpredaja (minulost' a prítomnost'). Rozdiely medzi starnutím návrhov formulovaných z pohl'adu prvej a tretej osoby majú zjavne odlišný dopad na vysokú a nízku relatívnu peňažnú úsporu, ktoré sú takmer protikladné. Vysoký relatívny návrh úspory starne rýchlejšie ako nízky relatívny, ale len z pohl’adu prvej osoby. Ak je návrh úspory z pohl'adu tretej osoby, starnutie je rýchlejšie v prípade nízkej relatívnej úspory a vysoký relatívny návrh úspory starne pomalšie. Zhodne s uvedeným, efekt rámcovania regulujú dva faktory: 1) starnutie návrhu peňažnej úspory a 2) osobný uhol pohl'adu na formuláciu návrhu úspory. 